\title{
New Naphthyl Substituted Phytosterol and Lanostane Type-triterpenic Esters from the Stem Bark of Ficus religiosa $\mathrm{L}$.
}

\author{
Abuzer Ali', Mohammad Jameel ${ }^{2}$, Mohammed Ali3,* \\ ${ }^{1}$ College of Pharmacy, Taif University, Taif, Al-Haweiah, SAUDI ARABIA. \\ ${ }^{2}$ Regional Research Institute of Unani Medicine, Central Council of Research Unani Medicine, Aligarh, Uttar Pradesh, INDIA. \\ ${ }^{3}$ Department of Pharmacognosy and Phytochemistry, School of Pharmaceutical Education and Research, Jamia Hamdard, New Delhi, \\ INDIA.
}

\begin{abstract}
Background: Ficus religiosa L. (Moraceae) is considered as a holy tree in most of the part of south-eastern Asia. Traditionally, its bark is used in the treatment of burns, diarrhoea, dysentery, gastrohelcosis and gonorrhoea, glandular swellings of the neck, scabies, piles, urogenital disorders, anxiety, vomiting, skin diseases and prescribed to improve the skin complexion. Materials and Methods: The methanol extract of stem bark of $F$. religiosa was obtained by continuous hot extraction process. Isolation of phytoconstituents was done by silica gel column chromatography. Analytical thin layer chromatography was used to check the homogeneity of eluted fractions. The structures of isolated compounds were established on the basis of $1 \mathrm{D}$ and 2D NMR, FT-IR, UV and MS data and chemical means. Results: Phytochemical investigation of the methanol extract of $F$. religiosa stem bark led to the isolation of a new naphthyl substituted phytosterol characterized as naphthyl-1', 3'-diol-1'-3 $\beta$-sitosteryl-3'-linoleinate (1) and a new lanostane type-triterpenic

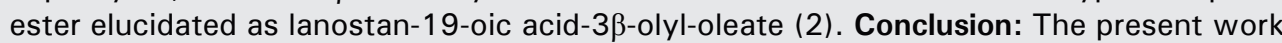
has enhanced the phytochemical profile of $F$. religiosa. Compound 1 and 2 have been isolated for the first time from this plant and might be used as chromatographic markers for the quality control analysis of its marketed herbal formulations.
\end{abstract}

Key words: Ficus religiosa, Stem bark, Phytosterol ester, Lanostanol ester, Isolation, characterization, $\beta$-sitosteryl naphthadiolyl linoleinate, Lanostanoic acid oleate.

\section{INTRODUCTION}

Ficus religiosa L. (Moraceae) tree, known as peepal, bodhi and ashwattha tree, is a native to India and south-eastern Asian countries. It is distributed in Egypt, Chad, Mexico and South America. It is a deciduous, laticiferous, fast growing tree, up to $25 \mathrm{~m}$ high; smooth bark grey in colour; spreading branches; simple, alternate, spiral ovate-lanceolate, puberulous leaves; unisexual, small, red flowers; inflorescence a syconia, sessile, axillary, in pairs, obovoid or globose; fruits small figs, purple on ripening. ${ }^{1-3}$ The leaves are purgative, leaf ash mixed with coconut oil is applied to subside boils; latex is tonic and put on to cure bleeding and swelling gums; fruits are aphrodisiac, purgative and given to relieve menstrual disorders, seeds are alterative and refrigerant. Traditionally it is used to treat asthma, bacterial infections, bronchitis, chicken pox, constipation, cough, diabetes, diarrhoea, elephantiasis, epilepsy, gastric problems, gonorrhoea, inflammation, leprosy, liver diseases, menstrual irregularities, migraine, sexual disorders, stomatitis, tuberculosis, ulcers and vomiting. ${ }^{4,5}$ The bark possesses aphrodisiac, anti-inflammatory, astringent, antiseptic and refrigerant properties, used to treat anxiety, boils, blisters, burns, diarrhoea, diabetes, dysentery, gastrohelcosis, gonorrhoea, inflammation, gout, piles, skin diseases, urinogenital disorders, vomiting, wounds
Submission Date: 28-01-2020; Revision Date: 27-04-2020; Accepted Date: 29-06-2020

DOI: 10.5530/ijper.54.3.126 Correspondence: Prof. Mohammed Ali Department of Pharmacognosy and Phytochemistry, School of Pharmaceutical Education and Research, Jamia Hamdard, New Delhi-110062, INDIA.

Phone: +919968281082 E-mail: maliphyto@gmail. com

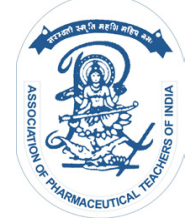

www.ijper.org 
and to improve skin complexion. The root bark is beneficial to control diabetes and its complications. ${ }^{1,6-8}$ Ayurvedic formulations, such as Nalpamaraditailam, Nyagrodhadi churna and Saribadyasavam contain F. religiosa bark as an important ingredient. ${ }^{9,10}$

Unsaturated and saturated fatty acids, cyclic fatty acid ester, fatty alcohols, ${ }^{11}$ tetrahydroxyoctanoic and tetrahydroxydecanoic acids, steryl naphthyl esters, ${ }^{12}$ phytosteroids, naphthyl esters, lanostanoic acid linolenate, ${ }^{13}$ lupen-3-one, lanosterol, coumarins, vitamin $\mathrm{K}_{1},{ }^{14-17}$ anthocyanidins, saponin, lupeol, $\alpha$-amyrin acetate, tannins and wax had been reported from the $F$. religiosa stem bark. ${ }^{18,19}$ Fruits contain fibre, hemicellulose, cellulose, lignin, pectin, asparagine, tyrosine, myricetin, quercetin, kaempferol and several volatile components. However, leaves furnish minerals, amino acids, campesterol, stigmasterol, sitosterol, a-amyrin, $\beta$-amyrin and lupeol. ${ }^{5,20}$ This article reports the isolation and structure elucidation of a new naphthyl substituted phytosterol and a new lanostane type-triterpenic ester from the stem bark of F. religiosa for the first time.

\section{MATERIALS AND METHODS General procedures}

Melting points of isolated phytoconstituents were determined by a thermoelectrical heated Perfit melting point apparatus. The IR spectra were recorded on an FT-IR (Bio-Rad) spectrometer in $\mathrm{KBr}$ pellet. Ultraviolet spectra were acquired with a Lambda Bio 20 spectrometer in methanol. ${ }^{1} \mathrm{H}(500 \mathrm{MHz})$, ${ }^{13} \mathrm{C}(125 \mathrm{MHz}), \mathrm{COSY}$ and HMBC NMR spectra of phytoconstituents were obtained on Bruker spectrospin spectrometer using TMS as internal standard. ESI MS studies were executed on a Waters Q-TOF Premier Mass spectrometer (Manchester, UK).

\section{Chromatographic conditions}

Isolation of phytoconstituents was performed on glass column chromatography using silica gel (mesh size: 60-120, Merck, India). Silica gel G (mesh size: 200-300) was utilized for preparative thin layer chromatography. Precoated TLC plates (Silica gel $60 \mathrm{~F}_{254}$ ) were utilized for analysis of eluents and the spots were visualized under UV lamp (254 and $366 \mathrm{~nm}$ ).

\section{Plant material}

Fresh stem bark of F. religiosa was collected from Delhi region and authenticated by Dr. H.B. Singh (taxonomist), National Institute of Science Communication and Information Resources (NISCAIR), New Delhi. A bark voucher specimen was placed with a number NISCAIR/
RHMD/Consult/-2010-11/1665/263 in the herbarium for future reference.

\section{Extraction and isolation}

The stem bark of F. religiosa $(1 \mathrm{~kg})$ was air dried and pulverized. Extraction of coarsely powdered bark was done exhaustively with methanol $(2.5 \mathrm{~L})$ using a Soxhlet apparatus at $80^{\circ} \mathrm{C}$ for $12 \mathrm{~h}$. The extract was filtered and evaporated in vacuum $(337 \mathrm{mbar})$ at $40^{\circ} \mathrm{C}$ to produce a brown semi-solid mass (193.3 g). The semi-solid mass $(100 \mathrm{~g})$ was dissolved in double distilled water $(500 \mathrm{ml})$ by continuous stirring and petroleum ether $(500 \mathrm{ml})$ was added. The aqueous fraction (95.14 g) was collected, dried and loaded over a silica gel (60-120 mesh) glass column. ${ }^{12}$ Elution of the column with $\mathrm{CHCl}_{3}$ alone and $\mathrm{CHCl}_{3}-\mathrm{MeOH}(97: 3 \mathrm{v} / \mathrm{v})$ mixture yielded compounds 1 and 2 (Figure 1). Further isolated compounds were purified by preparative thin layer chromatography and recrystallization.

\section{RESULTS}

The structure of new isolated phytoconstituents 1 and 2 were elucidated on the basis of NMR, IR, UV and ESI MS spectral data analysis.

\section{$\beta$-Sitosteryl naphthadiolyl linoleinate (1)}

Elution of the column with chloroform yielded yellow sticky mass of 1 , purified by preparative TLC (chloroform-methanol, 99:1), $412 \mathrm{mg}(0.412 \%$ yield): $\mathrm{R}$ 0.85 (chloroform-methanol, 99:1); $\mathrm{UV} \lambda_{\text {max }}(\mathrm{MeOH}): 247$ nm; m.p. $295-297^{\circ} \mathrm{C}$; IR $v_{\max }$ (KBr): 2928, 2841, 1721, $1642,1525,1441,1362,1240,1167,1081,973,759 \mathrm{~cm}^{-1}$; ${ }^{1} \mathrm{H}$ NMR $\left(\mathrm{CDCl}_{3}\right): \delta 7.67(1 \mathrm{H}, \mathrm{d}, J=8.0 \mathrm{~Hz}, \mathrm{H}-9), 7.52$ $\left(1 \mathrm{H}, \mathrm{d}, J=3.0 \mathrm{~Hz}, \mathrm{H}-2^{\prime}\right), 7.31\left(1 \mathrm{H}, \mathrm{d}, J=3.0 \mathrm{~Hz}, \mathrm{H}-4^{\prime}\right)$, 7.29 (1H, m, H-7'), 7.03 (1H, m, H-8'), 6.45 (1H, dd, $J$ = 3.0, $\left.8.5 \mathrm{~Hz}, \mathrm{H}-6^{\prime}\right), 5.79$ (1H, m, H-10"), $5.38(1 \mathrm{H}, \mathrm{m}$, H-12"), 5.30 (1H, m, H-15"), 5.22 (1H, m, H-13"), 5.10 (1H, m, H-9"), 4.95 (1H, m, H-16"), 4.07 (1H, brm, w $=16.5 \mathrm{~Hz}, \mathrm{H}-3 \alpha), 2.72\left(2 \mathrm{H}, \mathrm{m}, \mathrm{CH}_{2}\right), 2.31(2 \mathrm{H}, \mathrm{t}, J=$ $\left.7.5 \mathrm{~Hz}, \mathrm{H}_{2}-2^{\prime \prime}\right), 1.06$ (3H, brs, Me-19), 0.95 (3H, d, J = $6.5 \mathrm{~Hz}, \mathrm{Me}-21), 0.87(3 \mathrm{H}, \mathrm{d}, J=6.1 \mathrm{~Hz}, \mathrm{Me}-26), 0.83$ $\left(3 \mathrm{H}, \mathrm{t}, J=6.0 \mathrm{~Hz}, \mathrm{H}_{2}-18\right.$ ), 0.66 (3H, brs, Me-18), 2.27$1.18\left(49 \mathrm{H}, \mathrm{m}, 21 \times \mathrm{CH}_{2}, 7 \times \mathrm{CH}\right) ;{ }^{13} \mathrm{C} \mathrm{NMR}\left(\mathrm{CDCl}_{3}\right): \delta$ 37.27 (C-1), 31.94 (C-2), 71.76 (C-3), 42.26 (C-4), 140.76 (C-5), 121.67 (C-6), 33.90 (C-7), 31.66 (C-8), 50.13 (C-9), 37.12 (C-10), 21.24 (C-11), 39.43 (C-12), 43.50 (C-13), 56.77 (C-14), 23.07 (C-15), 27.22 (C-16), 56.05 (C-17), 11.88 (C-18), 19.31 (C-19), 37.89 (C-20), 19.07 (C-21), 33.94 (C-22), 25.64 (C-23), 45.85 (C-24), 29.53 (C-25), 17.72 (C-26), 18.02 (C-27), 26.09 (C-28), 12.01 (C-29), 166.82 (C-1'), 138.31 (C-2'), 152.25 (C-3'), 144.33 (C-4'), 130.89 (C-5'), 134.55 (C-6'), 115.48 (C-7'), 117.58 
(C-8'), 125.12 (C-9'), 150.87 (C-10'), 173.28 (C-1"), 34.21 (C-2"), 29.77 (C-3"), 24.76 (C-4"), 29.62 (C-5"), 29.64 (C-6"), 29.68 (C-7"), 29.71 (C-8"), 128.05 (C-9"), 118.84 (C-10"), 25.71 (C-11"), 128.85 (C-12"), 129.68 (C-13"), 25.74 (C-14"), 114.06 (C-15"), 109.83 (C-16"), 20.62 (C-17"), 14.11 (C-18"); ESI-MS m/ z (rel. int.): $816\left[\mathrm{M}^{+}\right.$ $\left(\mathrm{C}_{57} \mathrm{H}_{84} \mathrm{O}_{3}\right)(2.8), 413$ (30.1), 397 (11.2), 277 (33.5), 261 (3.7).

\section{Lanostanoic acid oleate (2)}

Elution of the column with chloroform-methanol (97:3) furnished yellow crystals of 2 , recrystallized from acetone, $378 \mathrm{mg}\left(0.378 \%\right.$ yield): $\mathrm{R}_{f} 0.34$ (chloroformmethanol, 99:1); UV $\lambda_{\max }(\mathrm{MeOH}): 209$ nm; m.p. 225$226^{\circ} \mathrm{C}$; IR $v_{\max }(\mathrm{KBr}): 3432,2938,2738,1721,1698$, 1642, 1417, 1389, 1242, 1169, 1024, $763 \mathrm{~cm}^{-1}$; ${ }^{1} \mathrm{H}$ NMR $\left(\mathrm{CDCl}_{3}\right): \delta 5.32\left(1 \mathrm{H}, \mathrm{m}, \mathrm{H}-9^{\prime}\right), 5.25\left(1 \mathrm{H}, \mathrm{m}, \mathrm{H}-10^{\prime}\right), 4.18$ $(1 \mathrm{H}, \mathrm{dd}, J=5.0,8.5 \mathrm{~Hz}, \mathrm{H}-3 \alpha), 0.95(3 \mathrm{H}, \mathrm{d}, J=6.5 \mathrm{~Hz}$, Me-21), 0.91 (3H, brs, Me-28), $0.85(3 \mathrm{H}, \mathrm{d}, J=6.6 \mathrm{~Hz}$, Me-26), $0.83(3 \mathrm{H}, \mathrm{d}, J=6.5 \mathrm{~Hz}, \mathrm{Me}-27), 0.81(3 \mathrm{H}, \mathrm{t}, J$ $=6.1 \mathrm{~Hz}, \mathrm{Me}-18), 0.78$ (3H, brs, Me-30), 0.75 (3H, brs, Me-29), 0.72 (3H, brs, Me-18), 2.32-1.11 (56H, m, $25 \times$ $\left.\mathrm{CH}_{2}, 6 \times \mathrm{CH}\right) ;{ }^{13} \mathrm{C} \mathrm{NMR}\left(\mathrm{CDCl}_{3}\right): \delta 39.29(\mathrm{C}-1), 29.10$ (C-2), 80.41 (C-3), 40.83 (C-4), 48.96 (C-5), 18.07 (C-6), 27.50 (C-7), 31.92 (C-8), 51.36 (C-9), 38.46 (C-10), 22.81 (C-11), 37.41 (C-12), 47.48 (C-13), 55.61 (C-14), 23.66 (C-15), 27.84 (C-16), 55.90 (C-17), 15.84 (C-18), 178.76 (C-19), 38.65 (C-20), 16.31 (C-21), 40.37 (C-22), 27.48 (C-23), 41.75 (C-24), 30.79 (C-25), 20.53 (C-26), 20.81 (C-27), 26.28 (C-28), 16.63 (C-29), 19.18 (C-30), 171.15 (C-1'), 35.16 (C-2'), 29.65 (C-3'), 29.57 (C-4'), 29.48 (C-5'), 29.18 (C-6'), 29.33 (C-7'), 29.71 (C-8'), 128.88 (C-9'), 128.62 (C-10'), 29.71 (C-11'), 29.65 (C-12'), 29.33 (C-13'), 29.71 (C-14'), 27.41 (C-15'), 27.48 (C-16'), 22.71 (C-17'), 14.16 (C-18'); ESI-MS m/z (rel. int.): 724 [M] ${ }^{+}$ $\left(\mathrm{C}_{48} \mathrm{H}_{84} \mathrm{O}_{6}\right)$ (2.3), 459 (4.3), 443 (2.8), 281 (12.2), 265 (10.3).

\section{DISCUSSION}

Compound 1, named $\beta$-sitosterol naphthadiolyl linoleinate, was obtained as a yellow sticky mass from chloroform eluants. Its IR spectrum showed absorption bands for ester groups $\left(1721 \mathrm{~cm}^{-1}\right)$, unsaturation $\left(1642 \mathrm{~cm}^{-1}\right)$, aromatic ring $\left(1525,1081 \mathrm{~cm}^{-1}\right)$ and long aliphatic chain $\left(759 \mathrm{~cm}^{-1}\right)$. On the basis of mass and ${ }^{13} \mathrm{C}$ NMR spectra the molecular ion peak of $\mathbf{1}$ was determined at $m / z 816$ consistent with a molecular formula of a $\beta$-sitosteryl naphthyl ester, $\mathrm{C}_{57} \mathrm{H}_{84} \mathrm{O}_{3}$. The ion fragments arising at $m / z 413\left[\mathrm{C}_{1^{-}} \mathrm{O}\right.$ fission, $\left.\mathrm{C}_{29} \mathrm{H}_{49} \mathrm{O}\right]^{+}$and $397\left[\mathrm{O}-\mathrm{C}_{3} \text { fission, } \mathrm{C}_{29} \mathrm{H}_{49}\right]^{+}$indicated that $\beta$-sitosteryl unit was attached to the naphthyl moiety. The ion peaks generating at $m / z 261\left[\mathrm{O}_{-} \mathrm{C}_{1^{\prime \prime}}\right.$ fission, $\mathrm{CO}$
$\left.\left(\mathrm{CH}_{2}\right)_{7}(\mathrm{CH}=\mathrm{CH} \mathrm{CH})_{3} \mathrm{CH}_{3}\right]^{+}$and $277\left[\mathrm{C}_{3^{-}} \mathrm{O}\right.$ fission, $\left.\mathrm{OCO}\left(\mathrm{CH}_{2}\right)_{7} \quad\left(\mathrm{CH}=\mathrm{CH} \quad \mathrm{CH}_{2}\right)_{3} \quad \mathrm{CH}_{3}\right]^{+}$suggested the attachment of linoleinyl group to another carbon of the naphthyl moiety. The ${ }^{1} \mathrm{H}$ NMR spectrum of 1 exhibited four one-proton doublets at $\delta 7.67(J=8.0 \mathrm{~Hz}), 6.45$ $(J=8.5 \mathrm{~Hz}), 7.52(J=3.0 \mathrm{~Hz})$ and $7.31(J=3.0 \mathrm{~Hz})$ assigned to aromatic ortho-coupled $\mathrm{H}-9^{\prime}$ and $\mathrm{H}-\mathrm{G}^{\prime}$ and to meta-coupled $\mathrm{H}-2$ ' and $\mathrm{H}-4$ ' protons, respectively. The vinylic protons appeared as one-proton multiplets from $\delta 5.79$ to 4.95 . A one-proton broad multiplet at $\delta 4.07$ was attributed to oxygenated methine $\mathrm{H}-3 \alpha$ proton and its half width of $16.5 \mathrm{~Hz}$ suggested alpha orientation of the proton. A two-proton triplet at $\delta 2.31(J=7.5$ $\mathrm{Hz}$ ) was due to methylene $\mathrm{H}_{2}-2$ " protons adjacent to the ester group. Three three-proton doublets in the upward region at $\delta 0.95(J=6.5 \mathrm{~Hz}, \mathrm{Me}-21), 0.87(J=6.1 \mathrm{~Hz})$ and $0.85(J=6.3 \mathrm{~Hz})$ were attributed to $\mathrm{C}-21, \mathrm{C}-26$ and C-27 methyl protons. Two three-proton broad singlets at $\delta 1.01$ and 0.66 , a three-proton doublet at $\delta 0.95(J=$ $6.5 \mathrm{~Hz})$ and a three-proton triplet at $\delta 0.83(J=6.0 \mathrm{~Hz})$ were associated correspondingly with the tertiary C-19 and C-18, secondary C-21 and primary C-18" methyl protons, all of them located on the saturated carbons. The other methylene and methine protons resonated in the range of $\delta$ 2.27-1.18.

The ${ }^{13} \mathrm{C}$ NMR spectrum of 1 showed signals for ester carbon at $\delta 173.28(\mathrm{C}-1 \mathrm{l})$, aromatic carbons between $\delta$ 166.82-115.48, vinylic carbons between $\delta 140.76-109.43$ and methyl carbons from $\delta 22.59$ to 11.88 . The ${ }^{1} \mathrm{H}$ and ${ }^{13} \mathrm{C}$ NMR spectral data of the steroidal unit of 1 were compared with the reported data of similar steroids. ${ }^{21-23}$ The ${ }^{1} \mathrm{H}-{ }^{1} \mathrm{H}$ COSY spectrum of 1 exhibited correlations of $\mathrm{H}-3$ with $\mathrm{H}_{2}-2$; $\mathrm{H}-6$ with $\mathrm{H}_{2}-7$ and Me-19; $\mathrm{H}-24$ with $\mathrm{H}_{2}-23, \mathrm{Me}-26$ and Me-27; H-4' with $\mathrm{H}-2$ ' and H-6'; and $\mathrm{H}-12$ " with $\mathrm{H}-10 ", \mathrm{H}_{2}-11 "$ and $\mathrm{H}-13$ ". The HMBC spectrum of 1 displayed interactions of $\mathrm{H}-3, \mathrm{Me}-19$ and H-6 with C-5; $\mathrm{H}_{2}-23, \mathrm{H}-24, \mathrm{Me}-26$ and Me-27 with C-25; H-2', H-9' and $\mathrm{H}-3$ with $\mathrm{C}-1^{\prime}$; $\mathrm{H}-2^{\prime}$ and $\mathrm{H}_{2}-2$ " with $\mathrm{C}-1$ ";

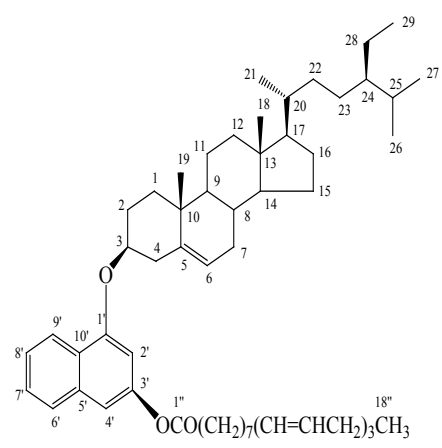

(1)

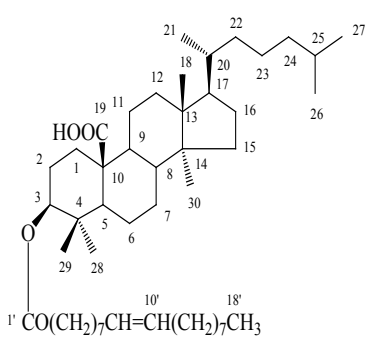

(2)
Figure 1: Structure of isolated compounds 1 and 2 from the stem bark of $F$. religiosa $L$. 
H-4', H-6' and H-7' with C-5'; and H-10", $\mathrm{H}_{2}-11^{\prime \prime}$ and H-13" with C-12". On the basis of above discussion, the structure of 1 has been characterized as naphthyl1',3'-diol-1'-3 $\beta$-sitosteryl-3'-linoleinate (Figure 1). This is a new naphthyl substituted phytosterol isolated for the first time from this plant.

Compound 2, designated as lanostanoic acid oleate, was obtained as a yellow crystalline mass from chloroformmethanol (97:3) eluants. It responded positively to Liebermann-Burchardt test for triterpenoid and yielded effervescences with sodium bicarbonate solution suggesting the presence of a carboxylic group. Its IR spectrum displayed absorption bands for an ester group $\left(1721 \mathrm{~cm}^{-1}\right)$, carboxylic function $\left(3432,1698 \mathrm{~cm}^{-1}\right)$, unsaturation $\left(1642 \mathrm{~cm}^{-1}\right)$ and long aliphatic chain $(763$ $\left.\mathrm{cm}^{-1}\right)$. On the basis of mass and ${ }^{13} \mathrm{C}$ NMR spectra the molecular ion peak of 2 was determined at $\mathrm{m} / \mathrm{z} 724$ consistent with the molecular formula of a lanostanoic acid ester, $\mathrm{C}_{48} \mathrm{H}_{84} \mathrm{O}_{6}$. The ion fragments arising at $m / z .459\left[\mathrm{C}_{1^{-}} \mathrm{O} \text { fission, } \mathrm{C}_{30} \mathrm{H}_{51} \mathrm{O}_{3}\right]^{+}, 443\left[\mathrm{O}_{-} \mathrm{C}_{3}\right.$ fission, $\left.\mathrm{C}_{30} \mathrm{H}_{51} \mathrm{O}_{2}\right]^{+}, 281\left[\mathrm{CH}_{3}-\left(\mathrm{CH}_{2}\right)_{7}-\mathrm{CH}=\mathrm{CH}-\left(\mathrm{CH}_{2}\right)_{7}-\mathrm{COO}\right.$, $\left.\mathrm{C}_{18} \mathrm{H}_{33} \mathrm{O}_{2}\right]^{+}$and $265\left[\mathrm{CH}_{3}-\left(\mathrm{CH}_{2}\right)_{7}-\mathrm{CH}=\mathrm{CH}-\left(\mathrm{CH}_{2}\right)_{7}-\mathrm{CO}\right.$, $\left.\mathrm{C}_{18} \mathrm{H}_{33} \mathrm{O}\right]^{+}$indicated the attachment of oleiyl group to lanostan-19-oic acid unit. The ${ }^{1} \mathrm{H}$ NMR spectrum of 2 exhibited two one-proton multiplets at $\delta 5.32$ and 5.25 assigned to vinylic $\mathrm{H}-\mathrm{9}^{\prime}$ and $\mathrm{H}-10^{\prime}$ protons, respectively. A one-proton double doublet at $\delta 4.18$ with coupling interactions of 5.0 and $8.5 \mathrm{~Hz}$ was attributed to oxygenated methine $\mathrm{H}-3 \alpha$ proton. Three three-proton doublets at $\delta 0.95(J=6.5 \mathrm{~Hz}), 0.85(J=6.6 \mathrm{~Hz})$ and $0.83(J=6.5 \mathrm{~Hz})$ were ascribed to C-21, C-26 and C-27 methyl protons, respectively. Four three-proton broad singlets at $\delta 0.91,0.78,0.75$ and 0.72 were associated correspondingly with the tertiary C-28, C-30, C-29 and $\mathrm{C}-18$ methyl protons. A three-proton triplet at $\delta 0.81(\mathrm{~J}$ $=6.1 \mathrm{~Hz}$ ) was due to primary C-18' methyl protons. The other methylene and methine protons resonated in the range of $\delta 2.32-1.11$.

The ${ }^{13} \mathrm{C}$ NMR spectrum of 2 showed signals for carboxylic carbon $\delta 178.76$ (C-19), ester carbon at $\delta$ $171.15\left(\mathrm{C}-1^{\prime}\right)$, vinylic carbons at $\delta 128.88\left(\mathrm{C}^{\prime} 9^{\prime}\right)$ and 128.62 (C-10') and methyl carbons from $\delta 26.28$ to 14.16. The ${ }^{1} \mathrm{H}$ and ${ }^{13} \mathrm{C}$ NMR spectral data of the triterpenic unit of 2 were compared with the reported data of lanostene-type triterpenoids. ${ }^{24-26}$ The ${ }^{1} \mathrm{H}-{ }^{1} \mathrm{H}$ COSY spectrum of 2 showed correlations of $\mathrm{H}-3$ with $\mathrm{H}_{2}-2$ and Me-28; $\mathrm{H}-5$ with Me-29, $\mathrm{H}_{2}-6$ and $\mathrm{H}_{2}-7$; $\mathrm{H}-25$ with $\mathrm{H}_{2}-24, \mathrm{Me}-26$ and $\mathrm{Me}-27$; and $\mathrm{H}-12^{\prime}$ with $\mathrm{H}-10$ ', $\mathrm{H}_{2}-11^{\prime}$ and $\mathrm{H}_{2}-13$ '. The HMBC spectrum of 2 showed interactions of Me-28, Me-29, H-3 and H-6 with C-5; $\mathrm{H}_{2}-23, \mathrm{H}_{2}-24$, Me-26 and Me-27 with $\mathrm{C}-25 ; \mathrm{H}_{2}-1$ and H-9 with C-19; and $\mathrm{H}-10^{\prime}, \mathrm{H}_{2}-11^{\prime}$ and $\mathrm{H}_{2}-13^{\prime}$ with $\mathrm{C}-12^{\prime}$.
On the basis of above discussion the structure of 2 has been elucidated as lanostan-19-oic acid-3 $\beta$-olyl-oleate (Figure 1). This is a new lanostane type-triterpenic ester isolated for the first time from this plant.

\section{CONCLUSION}

Chromatographic separation of methanolic extract of F. religiosa stem bark yielded a new naphthyl substituted phytosterol and a lanostane type-triterpenic ester for the first time. These new isolated compounds have enhanced the phytochemical profile of F. religiosa and may play important role as chromatographic chemical markers in quality analysis of its traditional formulations.

\section{ACKNOWLEDGEMENT}

The authors would like to express their gratitude to the instrumentation centre of the Faculty of Pharmacy, Jamia Hamdard, New Delhi, India for recording spectral data.

\section{CONFLICT OF INTEREST}

The authors confirm that the article content has no conflict of interest

\section{ABBREVIATIONS}

IR: Infrared Spectroscopy; KBr: Potassium Bromide; FT-IR: Fourier-Transform Infrared Spectroscopy; NMR: Nuclear Magnetic Resonance; COSY: Correlation Spectroscopy; HMBC: Heteronuclear Multiple Bond Correlation; TMS: Tetramethylsilane; ESI MS: Electrospray Ionization Mass Spectrometry; UV: Ultraviolet-Visible Spectroscopy; TLC: ThinLayer Chromatography; $\mathbf{C H C l}_{3}$ : Chloroform; $\mathbf{C D C l}_{3}$ : Deuterated Chloroform; $\mathbf{M e O H}$ : Methanol; d: Doublet; dd: Double doublet; m: Multiplet; brm: Broad Multiplet; Me: Methyl; Brs: Broad Singlet; rel. int.: Relative Intensity.

\section{REFERENCES}

1. Warrier PK, Nambiar VPK, Ramankutty C. Indian Medicinal Plants: A Compendium of 500 species. Chennai: Orient Longman Pvt. Ltd. 1995.

2. Anonymous. The Wealth of India: A dictionary of Indian Raw materials and industrial products (F-G). New Delhi: Council of Scientific and Industrial Research. 2005.

3. Babu K, Shankar SG, Rai S. Comparative pharmacognostic studies on the barks of four Ficus species. Turkish Journal of Botany. 2010;34(3):215-24.

4. Kirtikar KR, Basu BD. Indian Medicinal Plants. $2^{\text {nd }}$ ed. New Delhi: Periodical Experts Book Agency. 1993.

5. Singh D, Singh B, Goel RK. Traditional uses, phytochemistry and pharmacology of Ficus religiosa. Journal of Ethnopharmacology. 2011;134(3):565-83. 
6. Kapoor LD. Handbook of Ayurvedic Medicinal Plants. $1^{\text {st }}$ ed. Boca Raton: CRC Press. 1990.

7. Kaur A, Rana AC, Tiwari V, Sharma R, Kumar S. Review on ethanomedicinal and Pharmacological Properties of Ficus religiosa. Journal of Applied Pharmaceutical Science. 2011;1(8):6-11.

8. Quattrocchi U. CRC World Dictionary of Medicinal and Poisonous Plants: Common Names, Scientific Names, Eponyms, Synonyms and Etymology. $1^{\text {st }}$ ed. Boca Raton: CRC Press. 2012.

9. Sivarajan VV, Balachandran I. Ayurvedic drugs and their plant sources. $1^{\text {st }}$ ed. New Delhi: Oxford and IBH Publishing Co. 1994

10. Simha KRG, Laxminarayana V. Standardization of Ayurvedic polyherbal formulation Nyagrodhadi Churna. Indian Journal of Traditional Knowledge. 2007;6(4):648-52.

11. Ali A, Jameel M, Ali M. Fatty acids analysis of Ficus religiosa stem bark by gas chromatography-mass spectrometry. International Journal of Advances in Pharmacy Medicine and Bioallied Sciences. 2017a;(112):1-6.

12. Ali A, Jameel $M$, Ali M. A new naphthyl substituted $\beta$-sitosterol and fatty acids from the bark of Ficus religiosa L. Indian Drugs. 2017b;54(7):18-22.

13. Ali A, Jameel M, Ali M. New Naphthyl esters from the bark of Ficus religiosa Linn. The Natural Products Journal. 2014a;4(4):248-53.

14. Ambike $\mathrm{SH}, \mathrm{Rao} \mathrm{M}$. Studies on a phytosterol from the bark of Ficus religiosa. Indian Journal of Pharmacology. 1967;29(2):91-4.

15. Swami KD, Malik GS, Bisht NPS. Chemical investigation of stem bark of Ficus religiosa and Prosopis spicigera. Journal of the Indian Chemical Society. 1989;66(4):288-9.

16. Swami KD, Bisht NPS. Constituents of Ficus religiosa and Ficus infectoria and their biological activity. Journal of the Indian Chemical Society. 1996;73:6312.

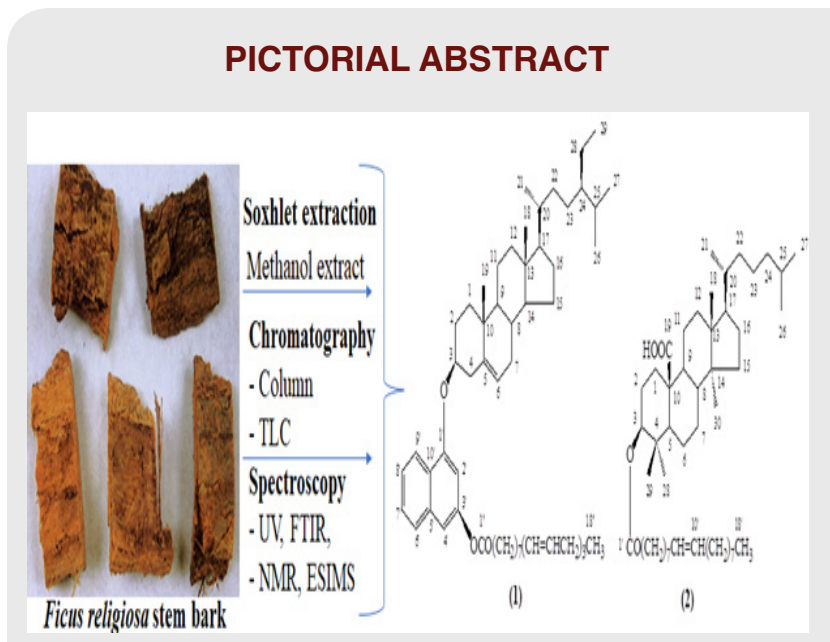

\section{About Authors}

Abuzer Ali, College of Pharmacy, Taif University, Taif, Al-Haweiah, SAUDI ARABIA.

Mohammad Jameel, Regional Research Institute of Unani Medicine, Central Council of Research Unani Medicine, Aligarh, Uttar Pradesh, INDIA.
17. Makhija IK, Sharma IP, Khamar D. Phytochemistry and Pharmacological properties of Ficus religiosa: An overview. Annals of Biological Research. 2010;1(4):171-80.

18. Husain A, Virmani OP, Popli SP, Misra LN, Gupta MM, Srivastava GN, et al Dictionary of Indian Medicinal Plants. $1^{\text {st }}$ ed. Lucknow: Central Institute of Medicinal and Aromatic Plants. 1992.

19. Joseph B, Justin SR. Phytopharmacological and phytochemical properties of three Ficus species: An Overview. International Journal of Pharma and Bio Science. 2010;1(4):246-53.

20. Deepa P, Sowndhararajan K, Kim S, Park SJ. A role of Ficus species in the management of diabetes mellitus: A review. Journal of Ethnopharmacology. 2018;215:210-32.

21. Akhtar N, Ali M, Alam MS. New steroidal glycosides from the stem bark of Mimusops elengi. Chemistry of Natural Compounds. 2010;46(4):549-53.

22. Mustafa A, Ali A. New steroidal lactones and homomonoterpenic glucoside from fruits of Malva sylvestris L. Acta Poloniae Pharmaceutica. 2011;68(3):393-401.

23. Jung WS, Chung IM, Ali M, Ahmad A. New steroidal glycoside ester and aliphatic acid from the fruits of Lycium chinense. Journal of Asian Natural Products Research. 2012;14(4):301-7.

24. Ali M. Techniques in Triterpenoid identification. $1^{\text {st }}$ ed. Delhi: Birla Publications. 2001.

25. Ahmad A, Ali M, Tandon S. New Oenotheralanosterol A and B constituents from the Oenothera biennis Roots. Chinese Journal of Chemistry. 2010;28(12):2474-8.

26. Shuaib M, Ali M, Naquvi KJ. Triterpenoid and steroidal esters from the roots of Operculina turpethum (L.) Silva Monso. Journal of Natural Product and Plant Resources. 2013;3(3):12-9

Mohammed Ali, Department of Pharmacognosy and Phytochemistry, School of Pharmaceutical Education and Research, Jamia Hamdard, New Delhi, INDIA.

Cite this article: Ali A, Jameel M, Ali M. New Naphthyl Substituted Phytosterol and Lanostane Type-triterpenic Esters from the Stem Bark of Ficus religiosa L. Indian J of Pharmaceutical Education and Research. 2020;54(3):750-4. 